\title{
Design of materials for solid oxide fuel cells cathodes and oxygen separation membranes based on fundamental studies of their oxygen mobility and surface reactivity
}

\author{
Vladislav Sadykov ${ }^{1,2, *}$, Ekaterina Sadovskaya ${ }^{1,2}$, Nikita Eremeev $^{1}$, Elena Pikalova $^{3,4}$, Nina \\ Bogdanovich $^{3}$, Elena Filonova ${ }^{4}$, Yulia Fedorova ${ }^{1}$, Alexey Krasnov ${ }^{1}$, Pavel Skriabin ${ }^{1}$, \\ and Anton Lukashevich ${ }^{1}$
}

${ }^{1}$ Boreskov Institute of Catalysis SB RAS, 630090 Novosibirsk, Russia

${ }^{2}$ Novosibirsk State University, 630090, Novosibirsk, Russia

${ }^{3}$ Institute of High Temperature Electrochemistry UB RAS, 620137 Yekaterinburg, Russia

${ }^{4}$ Ural Federal University, 620002 Yekaterinburg, Russia

\begin{abstract}
Design of materials for solid oxide fuel cells cathodes and oxygen separation membranes and studying their oxygen transport characteristics are important problems of modern hydrogen energy. In the current work, fundamentals of such materials design based on characterization of their oxygen mobility by oxygen isotope exchange with $\mathrm{C}^{18} \mathrm{O}_{2}$ and ${ }^{18} \mathrm{O}_{2}$ in flow and closed reactors for samples of Ruddlesden Popper-type oxides $\mathrm{Ln}_{2-\mathrm{x}} \mathrm{Ca}_{\mathrm{x}} \mathrm{NiO}_{4+\delta}$, perovskite-fluorite nanocomposites $\mathrm{PrNi}_{0.5} \mathrm{Co}_{0.5} \mathrm{O}_{3-\delta}-\mathrm{Ce}_{0.9} \mathrm{Y}_{0.1} \mathrm{O}_{2-\delta}$, etc. are presented. Fast oxygen transport was demonstrated for PNC - YDC $\left(D_{O} \sim 10^{-8} \mathrm{~cm}^{2} / \mathrm{s}\right.$ at $\left.700^{\circ} \mathrm{C}\right)$ nanocomposites due to domination of the fast diffusion channel involving oxygen of the fluorite phase with incorporated Pr cations and developed perovskite-fluorite interfaces. For LnCNO materials a high oxygen mobility $\left(D_{O} \sim 10^{-7} \mathrm{~cm}^{2} / \mathrm{s}\right.$ at $\left.700^{\circ} \mathrm{C}\right)$ provided by the cooperative mechanism of its migration was demonstrated. Depending on Ca dopant content and Ln cation nature, in some cases 1-2 additional channels of the slow diffusion appear due to decreasing the interstitial oxygen content and increasing the energy barrier for oxygen jumps due to cationic size effect. Optimized by the chemical composition and nanodomain structure materials of these types demonstrated a high performance as SOFC cathodes and functional layers in asymmetric supported oxygen separation membranes.
\end{abstract}

\section{Introduction}

Design of materials with mixed oxygen ion and electron conductivity (MIECs) for solid oxide fuel cells (SOFC) cathodes and catalytic membrane reactors for oxygen separation based on their oxygen transport characteristics is important problem of modern hydrogen

*Corresponding author: sadykov@ catalysis.ru 
energy [1-5]. Along with the microstructure features, the electrode performance correlates with the electrode material oxygen self-diffusion coefficient and surface exchange constant values $[6,7]$. For oxygen separation membranes' materials a high mixed ionic-electronic conductivity is required to obtain a high oxygen flux across the membrane providing efficient performance in catalytic reactions of fuels selective oxidation into syngas $[4,5]$.

Conventional perovskite materials such as Sr-doped La manganites, ferrites-nickelates, ferrites-cobaltites have problems in their thermomechanical and chemical compatibility with electrolyte materials as well as chemical stability such as carbonization in $\mathrm{CO}_{2}$-rich atmospheres, which limit their application [1-5]. Undoped perovskites with a larger size of A-cation (e.g. Pr nickelates-cobaltites) are promising materials for SOFC and membrane applications due to stability to carbonization, compatibility with electrolytes (such as doped ceria) and a high oxygen mobility and surface reactivity [4, 5, 8-10]. Ruddlesden - Popper phases (RP) are promising due to their moderate thermal expansion coefficients and a high mixed ionic-electronic conductivity. A high oxygen mobility of these materials (oxygen tracer diffusion coefficient $\sim 10^{-7} \mathrm{~cm}^{2} / \mathrm{s}$ at $700^{\circ} \mathrm{C}$ ) is provided by the cooperative mechanism of its migration involving both regular and highly mobile interstitial oxygen of perovskite and rock salt layers, respectively [5, 11-17].

In the current work, fundamentals of such materials design based on characterization of their oxygen mobility and surface reactivity by the temperature-programmed and isothermal oxygen isotope exchange with $\mathrm{C}^{18} \mathrm{O}_{2}$ and ${ }^{18} \mathrm{O}_{2}$ in flow and closed reactors with detailed mathematical modeling for powdered samples of Ruddlesden - Popper-type oxides $\mathrm{Ln}_{2-\mathrm{x}} \mathrm{Ca}_{\mathrm{x}} \mathrm{NiO}_{4+\delta}(\mathrm{Ln}=\mathrm{La}, x=0-0.3 ; \mathrm{Ln}=\mathrm{Pr}, x=0-0.6 ; \mathrm{Ln}=\mathrm{Nd}, x=0-0.5)$ and perovskite-fluorite nanocomposites $\mathrm{PrNi}_{0.5} \mathrm{Co}_{0.5} \mathrm{O}_{3-\delta}-\mathrm{Ce}_{0.9} \mathrm{Y}_{0.1} \mathrm{O}_{2-\delta}(\mathrm{PNC}-\mathrm{YDC}$ ) are presented. Performance studies of symmetric cells' electrodes, SOFC cathodes and functional layers of asymmetric supported oxygen separation membranes based on the materials involved are reviewed.

\section{Materials and methods}

$\mathrm{Ln}_{2-\mathrm{x}} \mathrm{Ca}_{\mathrm{x}} \mathrm{NiO}_{4+\delta}$ (LnNCO) were synthesized by a solution assisted solid state reaction techniques [14-17]. $\operatorname{PrNi}_{0.5} \mathrm{Co}_{0.5} \mathrm{O}_{3-\delta}$ (PNC) and $\mathrm{Ce}_{0.9} \mathrm{Y}_{0.1} \mathrm{O}_{2-\delta}$ (YDC) were synthesized by modified Pechini technique [8, 9]. PNC - YDC nanocomposite was synthesized from original PNC and YDC powders in weight ratio $1: 1$ by ultrasonic dispersion in isopropanol [8-10]. All materials were characterized by XRD and TEM with EDX-analysis [8-10, 14-17]. The XRD data were fitted using Rietveld software.

Oxygen mobility and surface reactivity of materials were studied by oxygen isotope exchange with $\mathrm{C}^{18} \mathrm{O}_{2}$ and ${ }^{18} \mathrm{O}_{2}$ in temperature-programmed (TPIE) and isothermal modes using flow and closed reactors. Gas composition was monitored by SRS QMS200 (for closed reactor experiments) and UGA-200 (Stanford Research Systems, USA) (for flow reactor experiments) mass spectrometers. Responses of ${ }^{18} \mathrm{O}$ atoms fraction $(\alpha)$ and ${ }^{16} \mathrm{O}^{18} \mathrm{O}$ (or $\mathrm{C}^{16} \mathrm{O}^{18} \mathrm{O}$ ) molecules fraction $\left(f_{16-18}\right)$ in the gas phase were analyzed using mathematical model $[5,18,19]$ :

$$
\begin{aligned}
& \frac{\partial \alpha_{g}}{\partial t}+O(\tau)=\frac{N_{S}}{N_{g}} R^{\Sigma}\left(\alpha_{s}-\alpha_{g}\right) \\
& \frac{\partial \alpha_{s}}{\partial t}=R^{\Sigma}\left(\alpha_{g}-\alpha_{s}\right)-\left.\frac{N_{b u l k}}{N_{s}} \frac{D^{*}}{h^{2}} \frac{\partial \alpha_{b u l k}}{\partial \eta}\right|_{\eta=0}
\end{aligned}
$$




$$
\begin{gathered}
\frac{\partial \alpha_{\text {bulk }}}{\partial t}=\frac{D^{*}}{h^{2}} \frac{\partial^{2} \alpha_{b u l k}}{\partial \eta^{2}} \\
\frac{\partial f_{16-18}}{\partial t}+O(\tau)= \\
R^{0}\left(2 \alpha_{g}\left(1-\alpha_{g}\right)-f_{16-18}\right)+\frac{N_{S}}{N_{g}}\left(R^{2}\left(2 \alpha_{s}\left(1-\alpha_{s}\right)-f_{16-18}\right)\right. \\
\left.+R^{1}\left(\alpha_{g}\left(1-\alpha_{s}\right)+\alpha_{s}\left(1-\alpha_{g}\right)-f_{16-18}\right)\right) .
\end{gathered}
$$

The initial and boundary conditions are: $\quad t=0 \Rightarrow \alpha_{i}=\alpha_{i}^{o}$. Here $\alpha_{g}, \alpha_{S}$ and $\alpha_{b u l k}$ are atomic fractions of ${ }^{18} \mathrm{O}$ in the gas phase, on the surface and in the bulk of samples, respectively; $N_{g}, N_{s}$ and $N_{\text {bulk }}$ are amounts of oxygen atoms in the gas phase, on the surface and in the bulk of samples respectively; $f_{16-18}$ is the molecular fraction of ${ }^{16} \mathrm{O}^{18} \mathrm{O}$ (in the case of exchange with $\mathrm{O}_{2}$ ) or $\mathrm{C}^{16} \mathrm{O}^{18} \mathrm{O}$ (in the case of exchange with $\mathrm{CO}_{2}$ ); $R^{0}, R^{1}, R^{2}$ are rates of exchange going by different types of mechanism according to Muzykantov classification; $R^{\Sigma}=0.5 R^{1}+R^{2}=k^{*} N_{b u l k} / V_{\text {sample }}$ is the total rate of heteroexchange, $k^{*}$ is the surface exchange constant, $V_{\text {sample }}$ is the total volume of sample; $D^{*}$ is the oxygen tracer diffusion coefficient; $h$ is characteristic particle size of the sample, $\eta$ is dimensionless parameter of the distance from the particle surface; $t$ is time; $O(\tau)$ is operator, which depends on the mass transport mode in the reactor:

$$
O(\tau)=\left\{\begin{array}{cc}
0 & \text { - for closed reactor } \\
\frac{1}{\tau} \frac{\partial \alpha_{g}\left(\text { or } f_{16-18}\right)}{\partial \xi} & \text { - for flow reactor }
\end{array}\right.
$$

$\tau$ is the contact time in the reactor, $\xi$ is dimensionless sample length. The exchange rates and tracer diffusion coefficients are considered to have dependence on temperature according to Arrhenius law:

$$
R^{(i)}=R_{r e f}^{(i)} e^{-\frac{E_{R(i)}}{R T^{\prime}}}, \quad D^{*}=D_{r e f}^{*} e^{-\frac{E_{D}}{R T^{\prime}}}, \quad T^{\prime}=\frac{T T_{r e f}}{T_{r e f}-T},
$$

where $R_{r e f}^{(i)}$ and $D_{r e f}^{*}$ are the exchange rate and tracer diffusion coefficient at the reference temperature $T_{r e f}, E_{R(i)}$ and $E_{D}$ are their effective activation energies [5, 18, 19].

Symmetrical cells were built using $\mathrm{Ce}_{0.8} \mathrm{Sm}_{0.2} \mathrm{O}_{1.9}$ electrolyte substrates [14, 20, 21]. Functional cathode layers were formed on the electrolyte substrates followed by sintering at $1200-1300^{\circ} \mathrm{C}$. The estimated thickness of the functional layers after sintering was $\sim 25-28 \mu \mathrm{m}$ with porosity $\sim 35-40 \%$. The electrochemical study was carried out by using a Frequency Response Analyzer FRA-1260 with an electrochemical interface EI-1287 [14].

Single button anode supported solid oxides fuel cells were prepared using anodic $\mathrm{Ce}_{0.9} \mathrm{Y}_{0.1} \mathrm{O}_{2-\delta}\left|\mathrm{Ce}_{0.9} \mathrm{Gd}_{0.1} \mathrm{O}_{2-\delta}\right| \mathrm{Ni} / \mathrm{Zr}_{0.84} \mathrm{Y}_{0.16} \mathrm{O}_{2-\delta}$ half-cells as substrate. Cathode layers with thickness of $\sim 20 \mu \mathrm{m}$ were deposited on the substrate from inks prepared from powders and then sintered at $1100^{\circ} \mathrm{C}$. Voltammetric characteristics were obtained using humid hydrogen as fuel $(100 \mathrm{ml} / \mathrm{min})$ and dry compressed air as oxidant $(200 \mathrm{ml} / \mathrm{min})$ [8].

Asymmetric supported membranes (Fig. 1) for oxygen separation were built using $\mathrm{Ni} / \mathrm{Al}$ foam substrates. 


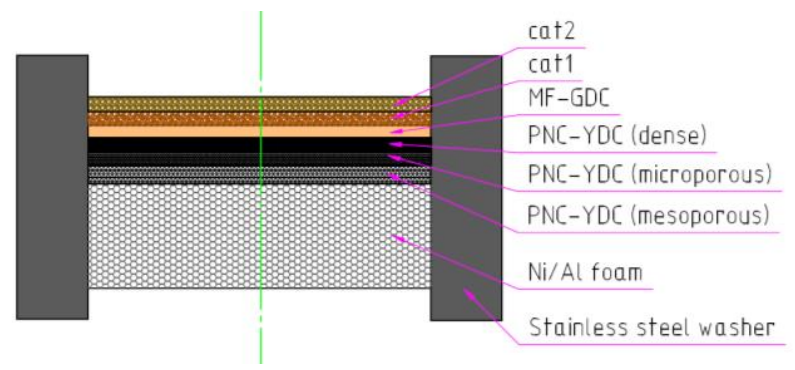

Fig. 1. Scheme of asymmetric supported oxygen separation membrane.

\section{Results and discussion}

\subsection{Structure features}

According to XRD data, LnNCO materials were single phase oxides with Ruddlesden Popper structure. The crystal structure was orthorhombic $(\mathrm{O})$ or tetragonal $(\mathrm{T})$ with space group Fmmm, I4/mmm or Bbcm depending on Ca doping level and, thus, interstitial oxygen content. Structure details and $\delta$ values are summarized in Table 1.

Table 1. Crystal structure and oxygen over-stoichiometry of the $\mathrm{Ln}_{2-\mathrm{x}} \mathrm{Ca}_{\mathrm{x}} \mathrm{NiO}_{4+\delta}$ materials.

\begin{tabular}{|c|c|c|c|c|c|c|c|c|}
\hline \multirow{2}{*}{ Sample } & \multicolumn{2}{|c|}{ La2-x $_{2} \mathbf{C a}_{\mathbf{x}} \mathbf{N i O}_{4+\boldsymbol{\delta}}$} & \multicolumn{3}{|c|}{ Pr$_{2-\mathbf{x}} \mathbf{C a}_{\mathbf{x}} \mathbf{N i O}_{4+\boldsymbol{\delta}}$} & \multicolumn{3}{c|}{$\mathbf{N d}_{2-\mathbf{x}} \mathbf{C a}_{\mathbf{x}} \mathbf{N i O}_{4+\boldsymbol{\delta}}$} \\
\hline$x$ & 0.0 & 0.3 & 0.0 & 0.3 & 0.5 & 0.0 & 0.3 & 0.5 \\
\hline Structure & $\mathrm{O}$ & $\mathrm{T}$ & $\mathrm{O}$ & $\mathrm{T}$ & $\mathrm{O}$ & $\mathrm{O}$ & $\mathrm{T}$ & $\mathrm{O}$ \\
\hline Sp. gr. & $F m m m$ & $I 4 / \mathrm{mmm}$ & $F m m m$ & $I 4 / \mathrm{mmm}$ & $B b c m$ & $F m m m$ & $I 4 / \mathrm{mmm}$ & $B b c m$ \\
\hline$a,[\AA]$ & 5.4629 & 3.8288 & 5.3923 & 3.8044 & 5.3373 & 5.3759 & 3.7993 & 5.3107 \\
\hline$b,[\AA]$ & 5.4664 & 3.8288 & 5.4610 & 3.8044 & 5.3590 & 5.4596 & 3.7993 & 53959 \\
\hline$c,[\AA]$ & 12.6828 & 12.5984 & 12.4441 & 12.3900 & 12.3590 & 12.3652 & 12.2928 & 12.2327 \\
\hline$\delta\left(25^{\circ} \mathrm{C}\right)$ & 0.13 & 0.06 & 0.25 & 0.09 & 0.01 & 0.20 & 0.11 & 0.04 \\
\hline
\end{tabular}

The XRD pattern of the PNC - YDC nanocomposite sintered at $1100^{\circ} \mathrm{C}$ is presented in Fig. 2. The unit cell parameters are $a=5.3750 \AA, b=7.6040 \AA, c=5.3960 \AA$ for perovskite phase and $a=5.4030 \AA$ for fluorite phase. The average X-ray particle size is $>100 \mathrm{~nm}$. The redistribution of cations between phases takes place via incorporation of Pr cations into doped ceria phase, which disorders both phases. The average compositions of perovskite and fluorite phases are $\operatorname{Pr}_{0.8} \mathrm{Ni}_{0.5} \mathrm{Co}_{0.5} \mathrm{O}_{3-\delta}$ and $\mathrm{Ce}_{0.65} \operatorname{Pr}_{0.25} \mathrm{Y}_{0.1} \mathrm{O}_{2-\delta}$ [4, 5, 8-10].

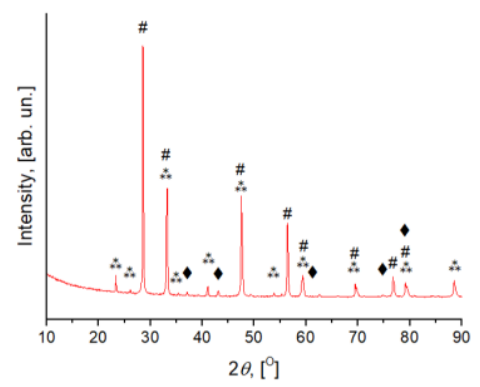

Fig. 2. XRD pattern of $\operatorname{PrNi}_{0.5} \mathrm{Co}_{0.5} \mathrm{O}_{3-\delta}-\mathrm{Ce}_{0.9} \mathrm{Y}_{0.1} \mathrm{O}_{2-\delta}$ nanocomposite. $\stackrel{\star}{*}-\mathrm{Pr}_{0.8} \mathrm{Ni}_{0.5} \mathrm{Co}_{0.5} \mathrm{O}_{3-\delta}$, \#$\mathrm{Ce}_{0.65} \mathrm{Pr}_{0.25} \mathrm{Y}_{0.1} \mathrm{O}_{2-\delta}, \diamond-\mathrm{NiO}[8-10]$. 


\subsection{Oxygen mobility and surface reactivity}

Typical TPIE curves obtained for PNC - YDC nanocomposite are given in Fig. 3(a). According to TPIE data modelling, two channel of oxygen diffusion related to perovskite (slow) and fluorite phases and interfaces (fast) were revealed; the oxygen tracer diffusion coefficient $D^{*}$ is $\sim 10^{-8} \mathrm{~cm}^{2} / \mathrm{s}$ at $700^{\circ} \mathrm{C}$ for fast diffusion channel (Fig. 3(b)). Thus, fast oxygen transport was demonstrated for PNC - YDC with domination of the fast diffusion channel involving $\sim 70 \%$ of bulk oxygen. These transport properties are provided by structural features (fluorite phase with incorporated Pr cations having a high oxygen mobility due to $\operatorname{Pr}^{3+/ 4+}$ chains) and developed perovskite-fluorite interfaces [4, 5, 8-10].
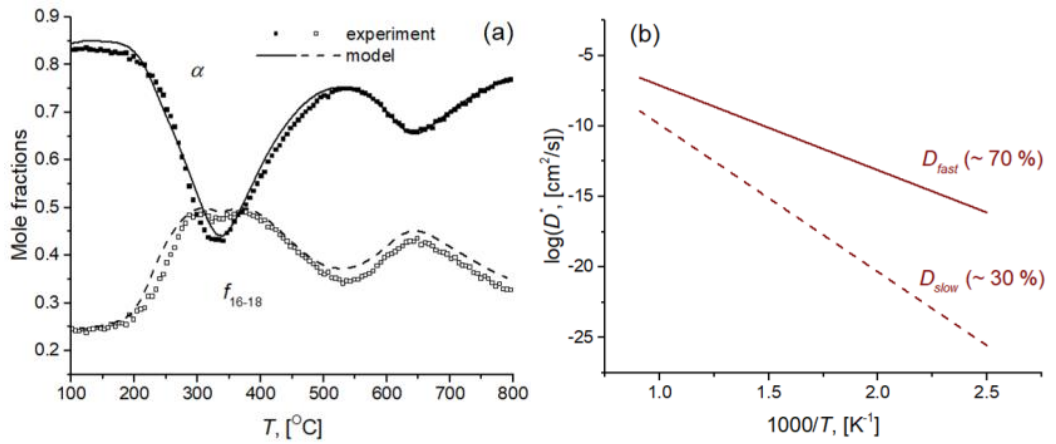

Fig. 3. Temperature- programmed isotope oxygen exchange with $\mathrm{C}^{18} \mathrm{O}_{2}$ in flow reactor (a) and Arrhenius plots for oxygen tracer diffusion coefficient $\left(D^{*}\right)(\mathrm{b})$ for PNC - YDC [8-10].

For LnCNO materials a high oxygen mobility $\left(D^{*} \sim 10^{-7} \mathrm{~cm}^{2} / \mathrm{s}\right.$ at $\left.700^{\circ} \mathrm{C}\right)$ was demonstrated. This is provided by the cooperative mechanism of its migration involving both interstitial and regular oxygen $[12,13]$. Doping with $\mathrm{Ca}$ decreases oxygen mobility due to decreasing the interstitial oxygen content as charge compensation and increasing the energy barrier for oxygen jumps between the interstitial and apical positions in octahedral layers due to cationic size effect. Depending on Ca dopant content and Ln cation nature, in some cases 1-2 additional channels of the slow diffusion appear [14-17, 24]. TPIE curves for the sample with 3 diffusion channels are given in Fig. 4. Comparison of $D^{*}$ values depending on the dopant content and Ln cation nature is shown in Fig. 5.

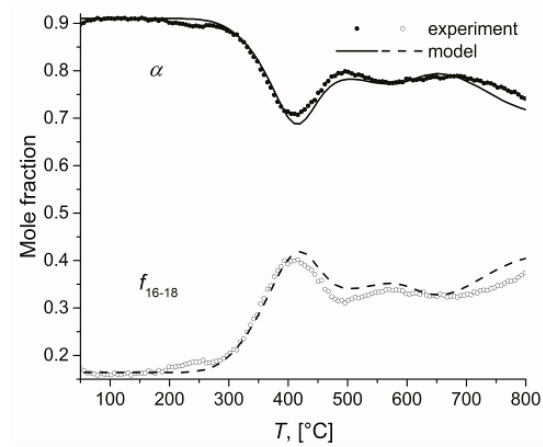

Fig. 4. Temperature programmed isotope exchange of oxygen with $\mathrm{C}^{18} \mathrm{O}_{2}$ in the flow reactor for $\mathrm{Pr}_{1.4} \mathrm{Ca} 0.6 \mathrm{NiO}_{4+\delta}$ sample. 

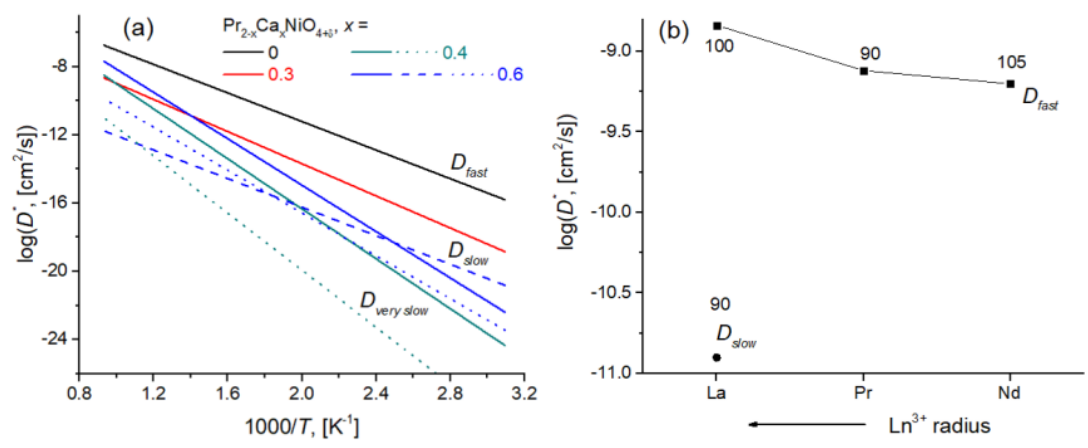

Fig. 5. (a) Arrhenius plots of oxygen tracer diffusion coefficient for $\operatorname{Pr}_{2-x} \mathrm{Ca}_{x} \mathrm{NiO}_{4+\delta}$ according to modelling of TPIE with $\mathrm{C}^{18} \mathrm{O}_{2}$ [15]. (b) Oxygen tracer diffusion coefficients at $700^{\circ} \mathrm{C}$ depending on $\mathrm{Ln}$ nature for $\mathrm{Ln}_{1.7} \mathrm{Ca}_{0.3} \mathrm{NiO}_{4+\delta}$; labels are effective activation energy values, [kJ/mole] [14-17].

\subsection{Performance of symmetric and solid oxide fuel cells}

The studies performed for the symmetrical cells with LnCNO functional layers have shown that the influence of $\mathrm{Ca}$ doping reveals itself differently in dependence on the nature of lanthanide $[14,15,17,20,21]$. However, in all cases there was no direct interrelation of the electrode activity with either the electrical properties or the interstitial oxygen content. In the case of La-based materials Ca doping drastically increased the polarization resistance of the electrodes (at $700^{\circ} \mathrm{C}, 0.73$ and $4.01 \Omega \mathrm{cm}^{2}$ for $x=0.0$ and 0.3 , respectively), while conductivity increased (at $700^{\circ} \mathrm{C}, 58$ and $93 \mathrm{~S} / \mathrm{cm}$ ). In the case of Pr-based materials the lowest polarization resistance was obtained at $x=0.1\left(0.17 \Omega \mathrm{cm}^{2}\right)$ while the maximal conductivity was reached at $x=0.5(145 \mathrm{~S} / \mathrm{cm})$. In the case of Nd-based materials the lowest polarization resistance was obtained at $x=0.4\left(0.37 \Omega \mathrm{cm}^{2}\right)$, at the same time the maximal conductivity was reached at $x=0.3(133 \mathrm{~S} / \mathrm{cm})$. We have revealed correlation of the polarization resistance of the electrodes with characteristics of oxygen transfer in the electrode material (self-diffusion coefficient, surface exchange constant) (Fig. 6). It was found that the electrochemical characteristics of the materials studied are inversely proportional to the product of the self-diffusion coefficient of oxygen and surface exchange constant, which corresponds to the theoretical model of the relationship between the diffusion impedance and the kinetic parameters of the electrode materials $[6,7]$.

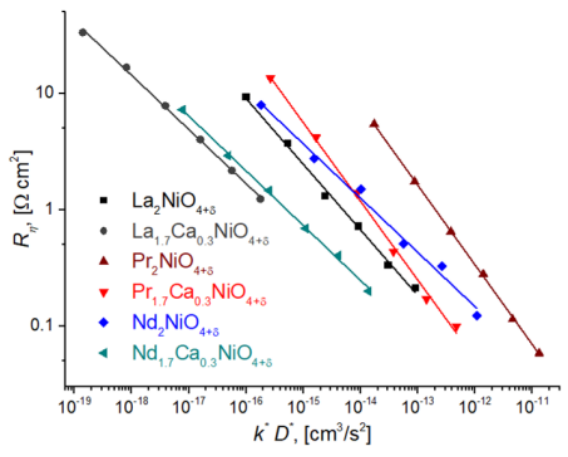

Fig. 6. Correlation between polarization resistance $\left(R_{\eta}\right)$ and oxygen transport characteristics [14-17, 24].

$\mathrm{Pr}_{2} \mathrm{NiO}_{4+\delta}$ and $\mathrm{PrNi}_{0.5} \mathrm{Co}_{0.5} \mathrm{O}_{3-\delta}-\mathrm{Ce}_{0.9} \mathrm{Y}_{0.1} \mathrm{O}_{2-\delta}$ were tested as cathodes of single-button solid oxide fuel cells. The maximum power density was $\sim 0.3 \mathrm{~W} / \mathrm{cm}^{2}$ at $600^{\circ} \mathrm{C}$, which is 
comparable or even higher than that for SOFCs with LSM and LSFC cathodes deposited on the same anode half-sells $[5,8]$.

\subsection{Performance of asymmetric supported membranes for oxygen separation}

In $\mathrm{CH}_{4}$ partial oxidation and oxi-dry reforming, carbonization of membrane surface was negligible. Syngas selectivity in $\mathrm{CH}_{4}$ partial oxidation increases with $\mathrm{CH}_{4}$ inlet fraction and temperature (Fig. 7). Increase of syngas yield and decrease of $\mathrm{CO}_{2}$ content were observed in experiments with high feed rates. These performance characteristics are possible due to a high oxygen permeability (permeation flux up to $7-10 \mathrm{ml} \mathrm{O}_{2} /\left(\mathrm{cm}^{2} \mathrm{~min}\right)$ at $950^{\circ} \mathrm{C}$ ), which is provided by a high oxygen mobility of PNC-YDC nanocomposite [5, 22, 23].

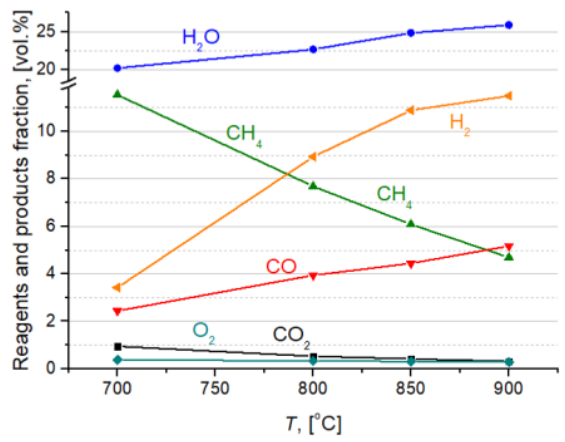

Fig. 7. $\mathrm{CH}_{4}$ partial oxidation in catalytic membrane reactor (feed $\mathrm{CH}_{4} 3.6 \mathrm{l} / \mathrm{h}$, air $1.5 \mathrm{l} / \mathrm{h}$ ).

\section{Conclusions}

Oxygen transport properties of novel materials for SOFC cathodes and oxygen separation membranes (Ruddlesden - Popper-type oxides, perovskite-fluorite nanocomposites) and their relationship with structural features were reviewed. Optimized by the chemical composition and nanodomain structure materials of these types demonstrated a high performance as SOFC cathodes and functional layers in asymmetric supported oxygen separation membranes used for transformation of biofuels into syngas.

Support by the Russian Science Foundation (Project 16-13-00112) is gratefully acknowledged. The authors from the Ural Federal University are grateful to the Government of the Russian Federation (Agreement 02.A03.21.0006, Act 211). $\mathrm{Ce}_{0.9} \mathrm{Y}_{0.1} \mathrm{O}_{2-\delta}\left|\mathrm{Ce}_{0.9} \mathrm{Gd}_{0.1} \mathrm{O}_{2-\delta}\right| \mathrm{Ni} / \mathrm{Zr}_{0.84} \mathrm{Y}_{0.16} \mathrm{O}_{2-\delta}$ anodic half-cells and $\mathrm{Ni} / \mathrm{Al}$ foam substrates were kindly provided by H.C. Starck, Germany and Powder Metallurgy Institute NAN Belarus, respectively.

\section{References}

1. B. C. H. Steele, A. Heinzel, Materials for fuel-cell technologies, in Materials for Sustainable Energy (World Scientific Publishing Co Pte Ltd, Co-Published with Macmillan Publishers Ltd, UK, 2010)

2. R. N. Basu, Materials for solid oxide fuel cells, in Recent Trends in Fuel Cell Science and Technology (Springer, New York, 2007)

3. R. M. Ormerod, Chem. Soc. Rev. 32, 17 (2003) 
4. V. A. Sadykov, S. N. Pavlova, T. S. Kharlamova, V. S. Muzykantov, N. F. Uvarov, Y. S. Okhlupin, A. V. Ishchenko, A. V. Bobin, N. V. Mezentseva, G. M. Alikina, A. I. Lukashevich, T. A. Krieger, T. V. Larina, N. N. Bulgakov, V. M. Tapilin, V. D. Belyaev, E. M. Sadovskaya, A. I. Boronin, V. A. Sobyanin, O. F. Bobrenok, A. L. Smirnova, O. L. Smorygo, J. A. Kilner,, Perovskites and their nanocomposites with fluorite-like oxides as materials for solid oxide fuel cells cathodes and oxygenconducting membranes: Mobility and reactivity of the surface/bulk oxygen as a key factor of their performance, in Perovskites: Structure, Properties and Uses, 76 (Nova Science Publishers, New York, 2010)

5. V. A. Sadykov, N. V. Mezentseva, L. N. Bobrova, O. L. Smorygo, N. F. Eremeev, Y. E. Fedorova, Y. N. Bespalko, P. I. Skriabin, A. V. Krasnov, A. I. Lukashevich, T. A. Krieger, E. M. Sadovskaya, V. D. Belyaev, A. N. Shmakov, Z. S. Vinokurov, V. A. Bolotov, Y. Y. Tanashev, M. V. Korobeynikov, M. A. Mikhailenko, Advanced materials for solid oxide fuel cells and membrane catalytic reactors (Chapter 12, 435-514 (Advanced Nanomaterials for Catalysis and Energy, V. A. Sadykov, Ed., Elsevier, 2019)

6. S. B. Adler, Chem. Rev. 104, 4791 (2004)

7. S. B. Adler, J. A. Lane, B. C. H. Steele, J. Electrochem. Soc. 143, 3554 (1996)

8. V. A. Sadykov, N. F. Eremeev, E. M. Sadovskaya, A. S. Bobin, Y. E. Fedorova, V. S. Muzykantov, N. V. Mezentseva, G. M. Alikina, T. A. Kriger, V. D. Belyaev, V. A. Rogov, A. S. Ulikhin, Yu. S. Okhlupin, N. F. Uvarov, O. F. Bobrenok, N. McDonald, J. Watton, A. Dhir, R. Steinberger-Wilckens, J. Mertens, I. C. Vinke, Russ. J. Electrochem. 50, 669 (2014)

9. V. Sadykov, N. Eremeev, G. Alikina, E. Sadovskaya, V. Muzykantov, V. Pelipenko, A. Bobin, T. Krieger, V. Belyaev, V. Ivanov, A. Ishchenko, V. Rogov, A. Ulihin, N. Uvarov, Yu. Okhlupin, J. Mertens, I. Vinke, Solid State Ionics 262, 707 (2014)

10. V. A. Sadykov, N. F. Eremeev, Z. S. Vinokurov, A. N. Shmakov, V. V. Kriventsov, A. I. Lukashevich, A. V. Krasnov, A. V. Ishchenko, J. Ceram. Sci. Technol. 8, 129 (2017)

11. G. Amow, I. J. Davidson, S. J. Skinner, Solid State Ionics 177, 1205 (2006)

12. P.-M. Geffroy, M. Reichmann, T. Chartier, J.-M. Bassat, J.-C. Grenier, J. Memb. Sci. 451, 234 (2014)

13. X. Li, N. A. Benedek, Chem. Mater. 27, 2647 (2015)

14. V. A. Sadykov, E. M. Sadovskaya, E. Y. Pikalova, A. A. Kolchugin, E. A. Filonova, S. M. Pikalov, N. F. Eremeev, A. V. Ishchenko, A. I. Lukashevich, J. M. Bassat, Ionics 24, 1181 (2018)

15. V. A. Sadykov, E. Y. Pikalova, A. A. Kolchugin, E. A. Filonova, E. M. Sadovskaya, N. F. Eremeev, A. V. Ishchenko, A. V. Fetisov, S. M. Pikalov, Solid State Ionics 317, 234 (2018)

16. E. Y. Pikalova, A. A. Kolchugin, V. A. Sadykov, E. M. Sadovskaya, E. A. Filonova, N. F. Eremeev, N. M. Bogdanovich, Int. J. Hydrogen Energy 43, 17373 (2018)

17. E.Yu. Pikalova, V.A. Sadykov, E.A. Filonova, N.F. Eremeev, E.M. Sadovskaya, N.M. Bogdanovich, S. Pikalov, J.G. Lyagaeva, A.A. Kolchugin, L.B. Vedmid', A.V. Ishchenko, V.B. Goncharov, Solid State Ionics 335, 53 (2019).

18. V. A. Sadykov, E. M. Sadovskaya, N. F. Uvarov, Russ. J. Electrochem. 51, 458 (2015)

19. V. Sadykov, E. Sadovskaya, A. Bobin, T. Kharlamova, N. Uvarov, A. Ulikhin, C. Argirusis, G. Sourkouni, V. Stathopoulos, Solid State Ionics 271, 69 (2015) 
20. A. A. Kolchugin, E. Y. Pikalova, N. M. Bogdanovich, D. I. Bronin, S. M. Pikalov, S. V. Plaksin, M. V. Ananyev, V. A .Eremin, Solid State Ionics 288, 48 (2016)

21. E. Y. Pikalova, N. M Bogdanovich, A. A. Kolchugin, D. A. Osinkin, D. I. Bronin, Procedia Eng. 98, 105 (2014)

22. V. A. Sadykov, Yu. E. Fedorova, A. I. Lukashevich, Z. Y. Vostrikov, N. F. Eremeev, A. V. Krasnov, P. I. Skryabin, O. L. Smorygo, Mat. Today Proc. 4, 11351 (2017)

23. V. A. Sadykov, A. V. Krasnov, Y. E. Fedorova, A. I. Lukashevich, Y. N. Bespalko, N. F. Eremeev, P. I. Skriabin, K. R. Valeev, O. L. Smorygo, Int. J. Hydrogen Energy (in press, doi: 10.1016/j.ijhydene.2018.02.182)

24. V. A. Sadykov, E. Yu. Pikalova, A. A. Kolchugin, A. V. Fetisov, E. M. Sadovskaya, E. A. Filonova, N. F. Eremeev, V. B. Goncharov, A. V. Krasnov, P. I. Skriabin, A. N. Shmakov, Z. S. Vinokurov, A. V. Ishchenko, S. M. Pikalov, Int. J. Hydrogen. Energy (in press, doi: 10.1016/j.ijhydene.2018.03.039) 